\title{
AN EVALUATION OF THE DEMAND FOR TELEWORK AND SMART WORK CENTRES IN RURAL AREAS: A CASE STUDY FROM LATVIA
}

\author{
Alise Vitola ${ }^{1}$, Iveta Baltina ${ }^{2}$
}

Received 10 May 2013; Accepted 20 September 2013

\begin{abstract}
Rural territories face significant challenges in a globalised world as the number of jobs in traditional rural sectors are decreasing. At the same time, information and communication technologies as well as the changes in professional duties allow the rural community to participate in the knowledge economy distantly. In order to evaluate the potential of telework 1335 inhabitants $(0.07 \%$ of the population) were surveyed in Latvia. A detailed analysis was conducted in two rural municipalities (Balvi and Limbazi) that face different socio-economic challenges. The results of the survey show a high demand for telework in Latvia rather insensitive to the gender, age and the place of residence of the respondents. People in less populated areas are also interested in socialising and professional networking activities in smart work centres - special premises for teleworking.
\end{abstract}

Keywords: telework, distant work, rural development, regional development

Kopsavilkums: Mūsdienu globalizētajā pasaulē lauku teritorijas saskaras ar būtiskiem izaicinājumiem, jo darbavietu skaits tradicionālajās lauku nozarēs samazinās. Tai pašā laikā informācijas un komunikāciju tehnoloǵijas, kā arī pārmaingas darba saturā un organizācijā lauj lauku kopienām piedalīties zināšanu ekonomikā attālināti. Lai novērtētu attālinātā darba potenciālu, tika aptaujāti 1335 jeb 0,07\% Latvijas iedzīvotāju. Detalizēta aptaujas rezultātu analīze tika veikta divās lauku pašvaldībās (Balvos un Limbažos), kas saskaras ar atšķirīgiem sociālekonomiskajiem izaicinājumiem. Aptaujas rezultāti liecina, ka Latvijā ir augsts pieprasijjums pēc teledarba iespējām, kas saglabājās līdzvērtīgs neatkarīgi no respondentu dzimuma, vecuma un dzīvesvietas. Cilvēki mazāk apdzīvotos reǵionos ir arī ieinteresēti socializēšanās un profesionālas tīklošanās aktivitātēs attālinātā darba centros telpās, kas veidotas teledarba veikšanai.

\section{Introduction}

The proportion of rural population is decreasing all over Europe; young and qualified people are the first to leave because of the lack of challenging jobs in the countryside. Research also

\footnotetext{
${ }^{1}$ Mg. oec. Alise Vitola, Institute of National and Regional Ekonomy, Kalku Street 1, 1658 Riga, Latvia; e-mail: vitola.alise@gmail.com)

${ }^{2}$ Iveta Baltina, PhD. student, Institute of National and Regional Ekonomy, Kalku Street 1, 1658 Riga, Latvia; e-mail: iveta.baltina@rtu.lv
} 
indicates a minor scale in migration of high-skilled professionals to remote areas. These people possess well-established contacts with the core markets and thus might have a significant positive impact on the local economy (Grimes, 2000). However, the in-migration of qualified professionals only to a small extent mitigates the decrease of socioeconomic activity in the periphery (Grimes, 2000).

As Brette and Moriset (2009) put it, "today's economy is submitted to a tension between centrifugal and centripetal forces, the outcome of which is uncertain". Undoubtedly, the concentration of resources in the agglomerations brings benefits to the economy. Large local market encourages the economy of scale; saturated job market allows the employers to hire the most suitable employees and vice versa; externalities as the transfer of knowledge and technologies raise the productivity of production. As Alfred Marshal has said, "the mysteries of the trade become no mystery, but are, as they were, in the air" (Krugman, 1998).Therefore some authors argue that the disparities in development are a natural consequence of capitalism (e.g. Grimes, 2000).

However, also the centrifugal forces play a role - not all resources are movable and can be reallocated to agglomerations (land) or are partly movable (human resources); the rise of the rent of land and also such externalities as the noise, pollution, stress etc. (Krugman, 1998). In fact, large agglomerations are territories that experience the most extreme values of different indicators such as income, education and employment (Grimes, 2000). Therefore also migration to less populated territories takes place.

For example, since the year 2000 Sweden has experienced a tendency of young families with children and elderly people moving from cities to rural areas, especially to territories with cultural and historical heritage. The main cause behind this life-cycle related migration is high living costs and expensive real estate in cities, proximity to nature, as well as children-friendly social and cultural environment. Majority of migrants return to the place they left to move to the city of where their ancestors come from (Nuur \& Laestadius, 2012). The Danish experience shows nowadays part of the previously self-sufficient rural communities have transformed into high-mobile residential and reproduction communities. However, not all rural territories have been lucky and consequently might be regarded as "winner villages" and "loser villages" (Moller, 2012).

A significant reason for such migration tendencies is the rural life-style which has deep rotes in such Northern European countries as Norway, Sweden and Finland. For example, the majority (52 $-57 \%$ ) of Swedes have an access to a second home in countryside; one fifth $(21 \%)$ owns such house. Academics, managers, officials from cultural institutions and public institutions have access to such homes more frequently (Nuur \& Laestadius, 2012).

Moreover, a notable share of global GDP today consists of immaterial (digital) content and services which are insensitive to distance (Brette and Moriset, 2009). Thus the information and communication technologies (hereinafter - ICT) allow reaching the concentration not only physically, but also virtually (digitally). ICT can also serve as an important tool to overcome the distance in rural areas and fully take advantage of its resources. Thus the opportunities provided by the ICT and the changes in the content of professional duties give the rural inhabitants a chance to participate in the knowledge economy, which is traditionally linked to metropolitan areas, distantly.

Indeed, an increasing share of businesses and other organizations are keen to use smart work (telework, distant work, e-work, mobile work) a widespread practice that allows employees and their tasks to be shared across settings away from central place of business or physical organizational location (Robertson \& Vink 2012).

The above mentioned rural development challenges (lower economic activity and consequently depopulation, unemployment, ageing) are topical also for Latvia which has experienced a rapid transformation of its economy from a centrally planned economy to market economy in the last two decades. Despite a wide network of small and medium sized towns, the economic activity has been concentrated in the capital city, Riga and the surrounding territories. Consequently 
the rural population (people living outside cities and towns) in Latvia is decreasing; in 1970 the proportion of rural inhabitants was $39 \%$, in $2011-32 \%$.

Researchers forecast that this proportion will decrease to $25-26 \%$ in 2020 due to an increase of productivity and a consequent decrease in the number of jobs in agriculture (Latvian State Institute of Agrarian Economics, 2011). Along with the decrease of the number of inhabitants in rural areas the relative costs to maintain the infrastructure and services will rise. That might lead to an even more rapid decrease of the rural population. Therefore it is crucial to search for alternatives to maintain jobs in rural areas.

Latvia is among the five European Union countries with the highest percentage of teleworkers (12\% compared to European Union average of $7 \%$ ) along with Czech Republic (15\%), Denmark $(14 \%)$, Belgium (13\%) and the Netherlands (12\%); teleworkers are considered employees who are doing telework for a quarter of the time or more (Welz and Wolf, 2010). Also our previous research points to a high potential of telework - up to 6 of 10 employees would like to use telework, especially young people (Baltina and Vitola, 2012). Moreover, the research by the University of Latvia in 2007 showed a significant potential for teleworking in Latvian regions; the respondents from the regions in Latvia - Latgale $(20.0 \%)$, Zemgale $(19.7 \%)$, Pieriga $(18.8 \%)$, Vidzeme and Kurzeme (in both 18.3\%) - would like to be involved in telework twice often than the employees in the capital city Riga (10.5\%) (Krisjane et al. 2007).

However, only few smart work centres are operational in Latvia, and all of them are located in the capital city Riga. In rural areas, part of the typical smart work services such as copying, scanning and printing services and the possibility to use a working place with a computer and a wireless internet connection are provided by public libraries or public internet points. Current developments in public library services in Latvia shows that 874 public libraries have already modernized and use contemporary information technology solutions that provide new informational and communication technologies and broadband wireless internet for smart work possibilities. Survey on the use of Latvian public libraries shows that in the year $201171.3 \%$ of all respondents ( $n=646$ ) used internet and library facilities for work related issues (SKDS, 2011).

Taking into account the above mentioned regional development challenges in Latvia and the experience of other European Union countries in the promotion of telework and the establishment of smart work centres in rural areas, the purpose of this research is to assess the demand for telework and smart work centre services outside metropolitan areas. As literature argues that ICT will stimulate the local economy only if technologies are integrated in the rural economies according to the needs of local inhabitants and entrepreneurs (Grimes, 2000), the demand for telework in rural areas is evaluated by analyzing the needs of local inhabitants.

Two sample municipalities, Limbazi and Balvi, are used for detailed analysis. The sample municipalities have a population density close to the average level in rural municipalities in Latvia (17 inhabitants per $\mathrm{km}^{2}$ ). Balvi municipality has 15 thousand inhabitants, Limbazi municipality -19 thousand inhabitants. Both municipalities experience negative socioeconomic development tendencies compared to the average indicators in Latvia. They have a higher rate of the depopulation compared to the average rate of depopulation in Latvia, as well as a lower proportion of children and youth, which points to a challenge in maintaining the current level of population.

Following the tendency that the level of socioeconomic development is highly dependent on the distance to the capital city (Locane et al., 2011), Balvi municipality, which is located $219 \mathrm{~km}$ from capital city Riga, has a higher unemployment level $(16,8 \%$ at the beginning of 2012) and the rate of depopulation (-5,9\%; in five years period - 2012 compared to 2007$)$ than Limbazi municipality $(11,1 \%$ and $-4,0 \%)$, which is located $87 \mathrm{~km}$ from the capital city Riga (Zvidrina et al., 2012). Therefore, the Limbaži municipality benefits from the relative proximity to the capital city and consequently has more positive development indicators than Balvi, which is located in the periphery and thus experiences more severe challenges. 
The results in these two municipalities are compared to the average results in Latvia. It allows for proposing suggestions to facilitate telework and consequently enhance employment and avoid further depopulation in rural areas facing socioeconomic development challenges.

The paper is organized as follows. The next section summarizes the literature review. The third section presents the methods used in this research. The fourth section presents the empirical findings of a survey made by the authors. The fifth section discusses the results in the light of literature review. The final section summarizes the main results and provides a perspective for policy-makers and future research.

\section{Literature review}

The origin of the smart work (telework, e-work, mobile work) - working independently of time and place with the help of ICT - came from the last century when Nilles first coined the term 'telecommuting' (Nilles, 1975; Bailey and Kurland, 2002; Pyoria 2003). Defined as working outside the conventional workplace and communicating with it by way of telecommunications or computer-based technology (Nilles, 1994; Olson and Primps, 1984) telework constitutes an early form of virtual work.

Definitions of telework rely on three main concepts: organization, location and technology. More than $60 \%$ of these definitions are based on a combination of at least two of these concepts. Since remote work and the use of new technology imply organizational changes, telework may be defined as work carried out in a location, where remote from central offices or production facilities, the worker has no personal contact with co-workers there, but is able to communicate with them using new technology. Within this broad definition, telework may be performed "online" or "offline", it may be organized individually or collectively, it may constitute all or part of the workers' job and it may be carried out by self-employed workers or by employees (Martino \& Wirth 1990).

There are potential direct and indirect benefits for teleworkers such as reduction of expenditure (fuel, car parking or public transport), reduction of commuting time, growth of productivity, elastic working time, de-reutilization of work, reduction of noise and stress at the office and an increase in mentoring opportunities. Telework also offers more time for family and friends, hobbies, improved work/life balance etc. (Bailey and Kurland, 2002; WorldatWork, 2011; Vermeylen and Hurley, 2007).

Higher educated workers are more likely to use telework. More than $10 \%$ of employees with professional, managerial and technical occupations are involved in telework (OECD, 2008). Teleworking is more frequent among firms that have larger percentages of knowledge employees in the workforce, e.g. product designers, software engineers, top managers, investment bankers etc. (Bailey and Kurland, 2002). Those industries where knowledge is a competitive resource are an ideal environment for teleworking adoption.

However, the "geographic paradox" of the digital economy shows that investments in sectors which are the main users of the new ICT tend to be located in large urban centres. The services off-shored to distant locations mainly consists of low qualification services such as call centres or services that might be divided into isolated modules such as software. (Brette and Moriset, 2009). Also the services off-shore have been most often transferred internationally to low costs countries not rural areas (Grimes, 2000).

Indeed, data proves that the potential of telework has not been fully discovered. In 2010 more than 740 million people migrated within their country, almost four times the extent of international migration. In the UK a working population of 29 million commuters in 2010 spent more than 20 million hours travelling to and from work every day, loosing at least an hour of their time and costing more than 266 million pounds a day in lost production (Gratton, 2011). In 2005 only $7 \%$ of the employed in the EU-27 were involved in smart work at least a quarter of the time. In comparison, in the United States the total number of people who worked from home or remotely for an entire day at least once a month in 2010 was $20 \%$ of the US working adult population of 139 million. $45 \%$ of the workforce holds a job that is compatible with at least part time telework (Welz and Wolf, 2010; Ozias, 2011). However, recent data show that 4 of 
5 workers would like to telework in the United States, but only $2,3 \%$ do it more than half the time (not including the self-employed) (Lister, 2012).

Telework, which has been proposed as a promising solution for rural development, continues to be an urban and suburban phenomenon. It might be explained by several factors. A face-toface communication is crucial for the transfer tacit knowledge and allows solving problems more efficiently. Thus the use of ICT may replace routine communication, but not the decision making. And only when face-to-face contacts are established they might be maintained by using ICT. Indeed, the experience shows that companies have been unwilling to outsource work to unknown distant teams (Grimes, 2000).

Also the habit to locate activities in the same places within a half-hour contact zone seems to be lasting (Brette \& Moriset 2009; Grimes, 2000). Moreover, there seems to be a temporal lag between the possibilities offered by the ICT and adaptation of behaviour. As Pyoria argues, "in order to make telework a viable alternative to more orthodox work practices, it has to be understood that a transition towards distributed organizations comprised of people connected mainly via ICTs is a large-scale social and cultural transformation that will not happen overnight" (Pyoria, 2003).

Moreover, the rigidness of the labour market plays a role, especially in households with both partners working; perhaps one of the partners has a job which he/she could perform also living in a rural area but the other not. Last but not least, the availability of high quality education and culture is an important factor when choosing the place of residence and it most often attracts residents to urban not rural areas (Brette \& Moriset, 2009).

Also the services offshored to distant locations mainly consists of low qualification services such as call centers or services that might be divided into isolated modules such as software (Brette \& Moriset, 2009). Moreover, the limited number of ICT users in rural areas leads to problems in establishing an advanced infrastructure. And the skills, as well as organisational and institutional capacity to exploit the potential offered by these technologies are even more important than the infrastructure (Grimes, 2000).

Experience also shows that one of the tools for the facilitation of smart work is the establishment of smart work centres, also called telework centres and co-working spaces (e.g. in France, United Kingdom, Hungary and Estonia). Smart work centres are special premises for smart workers considerably near the person's living place. Smart work centres have flexible and multifunctional use by offering numerous services that depends on the group of their users. The basic facilities offered by the smart work centre are a computer with appropriate programs, office equipment and ICT. Often smart work centres offers also additional services: an access to interactive technologies (e.g. high quality video conference), conference rooms, special recreation zone, large public rooms, day-care services for children, café or shop, financial services, IT support, employment services etc. (Connected urban development, 2012; Micropol, 2012). Smart work centres offer a stimulating environment for small businesses, selfemployed and employees of distant employers and thus may facilitate synergies among them.

Smart work centres bring benefits to employees, employers and local communities. Employees get the chance to live in a more peaceful, natural environment, decrease their commuting time, achieve a better work-life balance etc. Employers on the other hand can decrease personnel and operating costs and recruit better motivated employees. The local municipalities and communities can achieve an increased perception of the quality of life, advance economic activity and consequently local budget income. Moreover, smart work centres, especially those established as a bottom-up initiative, increase local social capital.

\section{Methods}

The research contains such qualitative research method as document analysis and such quantitative method as analysis of statistical data and the results of a survey. A literature study focuses on the recent publications and discusses telework as an instrument for the regional development. The analysis of statistical data from previous studies outlines the incidence and potential of telework in the world, Latvia and its territories. 
Furthermore, a questionnaire of inhabitants gives a more detailed picture on the incidence, willingness, benefits and drawbacks of telework in urban and rural areas. Survey was conducted from June to October 2012.

The questionnaire defined telework as a work form when the duties are being performed using ICT outside the premises of the employer, e.g. at home, in the library or other suitable premises. The definition of telework was included deliberately broad according to one defined in the European Framework Agreement. Article 2 of the European Framework Agreement on Telework of 2002 defines that "telework is a form of organizing and/or performing work, using information technology, in the context of an employment contract/ relationship, where work, which could also be performed at the employer's premises, is carried out away from those premises on a regular basis".

The questionnaire consisted of 14 questions representing three main groups of interest: 1) socio-demographic portrait of respondent including information on the place of residence, occupation and self-evaluation of ICT skills; 2) current habits for the use of ICT as well as potential interest in telework; 3) potential interest in smart work centre services.

The questionnaire was distributed in electronic way as well in paper version. The questionnaire was also distributed via such social networks as Facebook and draugiem.Iv - a Latvian analogue to Facebook. To get responses from the inhabitants of the Limbazi and Balvi municipalities (hereinafter - Limbazi and Balvi), local administrations were involved in the distribution of questionnaires. The questionnaire was addressed to collect the data on the demand for telework in the whole country, but the structure of questions allows analyzing results of Balvi and Limbazi separately.

1335 inhabitants $(0,07 \%$ of the population in Latvia) were surveyed, of them $768(58 \%)$ from capital city Riga, $138(10 \%)$ from other city municipalities (there are 9 city municipalities in Latvia, including Riga; each city has at least 25 thousand inhabitants) and 429 (32\%) from municipalities that include medium and small towns (towns with less than 25 thousand inhabitants). These categories correspond to the types of local municipalities (city and rural municipalities) in Latvia.

The majority of respondents represented the working age population. Only the opinion of economically active inhabitants $(929$ or $70 \%)$ is discussed in this article that represents $0,05 \%$ of inhabitants in Latvia. $758(82 \%)$ of respondents were employed by an employer, $102(11 \%)$ run their own business or were self-employed and $69(7 \%)$ - unemployed. $50 \%$ of respondents were up to 30 years old, $23 \%-31-40$ years old, $16 \%-41-50$ years old and $11 \%$ - more than 51 year old.

Representation of Balvi and Limbazi was relatively equal - 140 and 131 economically active respondents that represent $1 \%$ of inhabitants in these municipalities. Compared to the average results, the representation of unemployed respondents in both municipalities was two times higher than on average (14-15\%). Accordingly the share of employed (73\%) in Limbazi and the share of businessman and self-employed $(6 \%)$ in Balvi were lower than on average. In contradiction to the average results, the split of the number of respondents in age groups was relatively equal and varied from $22 \%$ to $30 \%$.

\section{Results}

\subsection{The willingness to be involved in smart work}

$83 \%$ of respondents were willing to be involved in telework $-82 \%$ in Riga, $87 \%$ in city municipalities (except Riga) and $83 \%$ in other municipalities. On average, $12 \%$ of respondents were not interested in telework. The highest interest was expressed by the age group of 41-50 $(88 \%)$, which was followed by the age groups 18-30 (84\%), 31-40 (81\%) and 51-62 (76\%). Regarding the employment status, $89 \%$ of businessmen and self-employed as well as $88 \%$ of the unemployed expressed an interest to being involved in telework. Also $81 \%$ of employed would like to telework. 
High interest to be involved in telework was expressed also in the sample municipalities. Higher interest was expressed in Balvi municipality (82\%) than in Limbazi $(76 \%) .9 \%$ of respondents in Limbazi and $5 \%$ of respondents in Balvi were not interested in telework. In Limbazi the highest interest to being involved in telework was among respondents in their thirties (85\%) and forties $(90 \%)$ whereas in Balvi - among respondents in their twenties (85\%) and forties (83\%), which is similar to the average results. In Limbazi, businessmen and self-employed had the largest interest to being involved in telework (100\% and $88 \%$ compared to an average of $76 \%$ ). In Balvi the highest interested had the unemployed and those who are working $(95 \%$ and $81 \%$ compared to an average of $82 \%$ ) whereas the businessman and self-employed showed a rather low interest $(67 \%)$.

In terms of saving time and costs, teleworking would bring benefits to $36 \%$ of respondents. It would save more than one hour, which is now being used for commuting, for $35 \%$ and 30 minutes to one hour for $31 \%$ of the respondents. However such benefits as work-life balance and flexible working hours were evaluated even higher $(58 \%)$ than the savings of time and costs. These benefits would be less significant in the sample municipalities as majority of the respondent use less than 30 minutes for travelling to work. On average, $27 \%$ of respondents from the non-city municipalities spent at least an hour and $23 \%-30$ minutes to an hour for daily commuting.

\subsection{The opinion on the use of the services of a smart work centre}

National statistics show that the majority of people use internet at home (89\%; multiple choices allowed), 36\% - at work, $5 \%$ - in an educational institution and 38\% - in other places such as library, internet cafe etc. (Central Bureau of Statistics 2012). Also this survey shows that the majority of inhabitants use ICT at home. Compared to the national statistics, the share of respondents using internet at work is much higher which could be explained by the choice to analyse only the answers from the economically active respondents. Still, one eighth of the respondents choose to use internet in the library or educational institution (Table 1).

The opinion on the willingness to use the services of smart work centre shows that only $14 \%$ of all respondents would be ready to work in a smart work centre if they had an opportunity to work distantly. The majority of the respondents $(77 \%)$ would prefer working at home. The respondents from other municipalities (16\%) were more interested in working in a smart work centre than respondents from city municipalities (12\%) and respondents from the capital city Riga (12\%).

\begin{tabular}{|l|c|c|c|}
\hline & Total $(\mathrm{n}=929)$ & Balvi $(\mathrm{n}=140)$ & Limbazi $(\mathrm{n}=131)$ \\
\hline From home & $83 \%$ & $78 \%$ & $68 \%$ \\
\hline From library & $12 \%$ & $20 \%$ & $13 \%$ \\
\hline $\begin{array}{l}\text { From education } \\
\text { institution }\end{array}$ & $16 \%$ & $4 \%$ & $1 \%$ \\
\hline From work & $66 \%$ & $49 \%$ & $53 \%$ \\
\hline
\end{tabular}

Tab 1. Opinion on existing practice - place where information and communication technologies are used.

Q: From which place do you usually perform tasks if you have to use of information technologies personal computer, printer, internet and other information technologies)?

Note: Percentages do not total $100 \%$ as respondents were allowed multiple choices.

Businessmen $(81 \%)$ had the highest share of those willing telework from home, whereas the unemployed had the highest proportion of respondents willing to work from a smart work centre (26\%). High interest to work from the smart work centre was expressed also by the selfemployed in city municipalities, including the capital city Riga ( $25 \%$ and $22 \%)$, and the businessman in rural municipalities (13\%). 
If a smart work centre was established respondents would be particularly interested in copying, scanning and printing services and the possibility to use a working place with a computer and a wire-less internet connection. $1 / 3$ of the respondents would find useful networking, mentoring and socialisation options, as well as business pre-incubation services. 1/5 of the respondents would find useful job matching and availability of a meeting room (Table 2).

\begin{tabular}{|l|c|c|c|}
\hline & Total $(\mathrm{n}=929)$ & Balvi $(\mathrm{n}=140)$ & Limbazi $(\mathrm{n}=131)$ \\
\hline Copying, scanning, printing & $22 \%$ & $24 \%$ & $17 \%$ \\
\hline $\begin{array}{l}\text { Access to personal computer and wireless } \\
\text { internet }\end{array}$ & $19 \%$ & $20 \%$ & $18 \%$ \\
\hline $\begin{array}{l}\text { Sharing ideas and knowledge (professional } \\
\text { networking) }\end{array}$ & $15 \%$ & $15 \%$ & $15 \%$ \\
\hline Start-up consultations (business pre-incubation) & $13 \%$ & $16 \%$ & $14 \%$ \\
\hline Meeting room & $11 \%$ & $6 \%$ & $7 \%$ \\
\hline Job matching & $10 \%$ & $13 \%$ & $13 \%$ \\
\hline Not interested & $11 \%$ & $6 \%$ & $15 \%$ \\
\hline
\end{tabular}

Tab 2. The opinion on the most useful services of smart work centre.

Q: If smart work centre - premises with access to personal computer and internet - would be established in your city, which services would you use?

Note: Percentages do not total $100 \%$ as respondents were allowed multiple choices.

The availability of working place and copying, scanning and printing services was considered very important by all respondents. The self-employed, businessman and unemployed stressed the importance of professional networking. The businessman would also be interested in using a meeting room whereas the self-employed and unemployed - in start-up consultations.

Also in the sample, municipalities majority of inhabitants choose to use ICT at home. However, the level of the use of internet was lower which could be explained by a lower accessibility of internet in rural areas. The practice to use ICT in the library was observed more often in the sample municipalities, especially by the unemployed (44\% in Limbazi and $27 \%$ in Balvi) and self-employed (20\% in Balvi). It reveals the important role of libraries as an internet provider in rural areas.

A preference to work distantly from home was expressed by $2 / 3$ of respondents also in the sample municipalities (76\% in Limbazi and $61 \%$ in Balvi). In Balvi respondents had a much higher interest to work in a smart work centre than on average $(26 \%)$, whereas in Limbazi relatively lower $(6 \%)$. In Balvi municipality the highest interest to work in a smart work centre was expressed by the businessmen (67\%) and unemployed (47\%). In Limbazi such services would be more interesting for the self-employed (13\%).

The evaluation of usefulness of the proposed smart work centre services in sample municipalities was rather similar to the average results. Higher interest was expressed regarding the start-up consultation and job matching which points to the employment challenges in these territories (Table 2).

\section{Discussion}

\subsection{Potential of smart work}

As notable share of professional duties shape an immaterial content and are therefore relatively insensitive to physical distance (Brette and Moriset, 2009), there is a potential in a wider use of telework. It could facilitate economic activity by offering more flexible job opportunities for already economically active people, as well as help to return to the labour market currently 
unemployed people. Moreover, a rise in telework might mitigate the disparities in regional development by allowing less populated territories to participate in the knowledge economy distantly.

Researchers point that telework should be supported by social and cultural transformations (Brette and Moriset 2009; Grimes 2000; Pyoria, 2003). Findings of this research show that people in Latvia are rather flexible (at least theoretically) regarding alternative work forms. The results of the survey show a high demand for telework in Latvia which is rather insensitive to the sex, age (except from respondents close to the official retirement age) and the place of residence of the respondents. Moreover, the proportion of respondents willing to be involved in telework $(83 \%)$ corresponds to similar result $(80 \%)$ in a survey of employed people in the United States (Lister, 2012) as well as our previous research in the public administration (Baltina\&Vitola, 2012), which points to the credibility of our survey.

Unemployed persons have an even higher interest in telework opportunities (88\%), especially in the Balvi municipality (95\%), which is located in the periphery. It indicates that telework has a potential (at least regarding the labour supply) to increase employment in rural areas. Also the latest survey of Australia proves the importance of telework for increasing employment possibilities. $70 \%$ of people not in the labour force living in remote locations of Australia reported they would take up a telework employment opportunity if it was made available (Australian Government, 2012). Available data on EU proves that a level of interest in telework is higher among the unemployed and other people looking for paid work (Gareis, 2002).

More detailed analysis regarding the age of potential teleworkers shows that not only young people (up to 30 years old) but even more respondents in their forties would like to be involved in telework. It corresponds to the results of previous surveys that showed a higher use of telework in professional and managerial occupations, as well as among knowledge workers (OECD, 2008; Bailey and Kurland, 2002).

Regarding the territorial allocation and employment status of potential teleworkers a relatively higher interest was expressed by the respondents from city municipalities (except the capital city Riga), businessmen and self-employed, as well as unemployed. A higher interested by the businessman and self-employed was shown by the respondents in Limbazi - a municipality close to the agglomeration of capital city, whereas in the peripheral Balvi municipality employed and unemployed were especially interested in telework opportunities. It points to the need to evaluate the local needs when making policies for the enhancement of telework.

The interest to be involved in telework shown in this research is 4 times higher regarding the regions than in the previous research in Latvia done by the Latvian University in 2007. It might be explained by a wider use of computers, electronic devices and the internet, e.g. from 2007 to 2012 the availability of a PC in a household increased from 49 to $70 \%$, the availability of internet - from 50 to $69 \%$ and the availability of broadband - from 32 to $67 \%$. The rise was especially rapid in the regions outside the capital city; in the least developed region Latgale figures rose 2 to 3 times. Also the proportion of people regularly using PC (from 55 to $70 \%$ ) and internet (from 52 to $70 \%$ ) has increased significantly. Furthermore, the high share of people using internet at home, which is even higher that the share of people using internet at work, points to a potential of telework. This could be explained by recently explored phenomena that "people had already begun to see their workplace technology lagging behind their personal investment in technology" (Gratton, 2011).

Moreover, the advancement of internet skills may be characterized by a rapid increase in the proportion of inhabitants communicating with public institutions via internet from 18 to $47 \%$, using internet banking from 28 to 47\% (Central Statistical Bureau of Republic of Latvia, 2012). However, also the coverage of our survey might be distorted; as the survey was distributed via internet and also via the service centres in municipalities and it is likely that the most active respondents replied.

Last but not least, research has pointed to other economic and social benefits of telework, e.g. saving time and costs, growth of productivity and more flexibility (Bailey and Kurland, 2002; Ozias, 2011; Vermeylen and Hurley, 2007). Also this survey shows that an increase in telework 
would bring both personal benefits and savings in terms of time and money for teleworkers, especially for the vast majority of respondents who spend at least 30 minutes in commuting daily. Moreover, personal benefits such as more flexibility and work-life balance were evaluated even higher than savings of time and money.

\subsection{Potential of smart work centres}

Previous research shows that smart work centres might be considered as positive instruments or tools for the development of deprived areas (Del AguilaObraet.al., 2002). Smart work centres - shared office spaces with ICT that support distant work - have been established in several European countries (United Kingdom, Hungary, Estonia, France etc.). In some cases smart work centres have been established by the regional and local authorities (e.g. Berwick WorkSpace in United Kingdom and smart work centre Nagykáta in Hungary), in some cases by local NGO's (e.g. Kõnnu and Kolga smart work centres in Estonia). Accordingly they differ significantly in their size. Some of the centres are integrated with business incubation services, some offer training, some child care facilities (Micropol, 2012).

In Latvia the establishment of smart work centres seems to be a promising option for a city (except Riga) and especially rural municipalities where respondents are less interested in working from home and more interested in working and using services in a smart work centre. It might be explained by a lower internet quality, less socialisation, networking and mentoring opportunities in these territories compared to the capital city.

In the sample municipalities we see a higher telework potential in Balvi than in Limbazi. Such difference might be explained by a relative closeness of Limbazi to capital city Riga and consequently more positive socioeconomic tendencies than in Balvi, which lies in the periphery. These findings also stress the need to search for new job opportunities in rural territories where the number of jobs in agriculture and public services is decreasing (Buldelberga et al., 2011).

In both municipalities the self-employed and businessmen showed the highest interest in the services of smart work centres, in Balvi - also the unemployed. It suggests that smart work centres could serve as a service point for start-ups and small businesses, in peripheral territories with severe employment problems - also for the integration of the unemployed in the labour market. These findings approve that each territory should search for the most appropriate form of smart work centre. As Grimes (2000) points, the ICT should be integrated in the local economies according to the needs of inhabitants.

However, the possibility to generate employment and income has been a challenge for majority of such centres a decade ago (Del Aguila Obra et. al., 2002). Indeed, the establishment of a smart work centre outside metropolitan regions seems to be a challenging task. The proportion of free-lancers might be lower, therefore additional functions such as training and help in searching job opportunities might be crucial. A promising solution might be the establishment of smart work centres in the towns with universities and vocational schools where the young generation - the future high-skilled workforce - concentrates.

Since the unemployment tends to be highest in the peripheral and remote regions of the European Community, these regions can be described as having a greater mismatch between telework demand and supply than the central regions (Gareis, 2002). Therefore, in rural territories, smart work centres could be closely coordinated with the delivery of public services and placed in already actively used premises, such as libraries, schools or community centres. Moreover, smart work centres could cooperate with an already working business support infrastructure offering consultation and support for the business start-ups. Thus such centres could help to raise the critical mass and would act as the facilitators of economic activity in the regions. In order to evaluate these options, additional research is required to offer sustainable solutions for employers to facilitate teleworking and smart work options in nonmetropolitan areas.

Last but not least, special attention should be paid in the integration of local and in-migrant professionals in the work of smart work centres. These people have well established contacts 
and thus might bring additional jobs to the territories, as well as act as mentors for start-ups. As Grimes (2000) points, such people have a significant positive impact on the local economy.

\subsection{Libraries as an option for creating smart work centres}

The results proves that majority of people use internet and ICT at home. This can be explained by the tendency of people to invest in home-based technologies. By 2010, the gulf between personal and corporate use of technology had already begun to narrow as more people decided to invest in home-based technology rather than rely on the technology companies provided for them (Graton, 2010). Indeed, a much higher interest in the services of smart work centres than a preference for working at such centres suggests that smart work centres should include hotdesking options for people visiting the centre time after time. Furthermore, a relatively high interest in the services of smart work centre from the unemployed and students suggests that smart work centres should act as multifunctional business centres/work hubs for different target groups. They should offer not only work spaces and ICT, but also professional training, career consultations, consultations in starting and managing business, job matching services, as well as networking and mentoring opportunities.

The estimation of services which inhabitants would be ready to use in smart work centre shows that these are the same which are provided by public libraries such as copying, scanning and printing services and working place with personal computer and wireless internet. The possibility to meet people and share ideas would be an issue to be considered for development of current library network in the new perspective. The key aspects to be considered thinking on the role of libraries in economic development and creating jobs would be the exchange of information and a known knowledge creation. The key here is flexibility, interdisciplinary cooperation and rapid learning, which can be seen as necessary competencies for successful smart working.

Current developments in public library facility services in Latvia shows that already 874 public libraries have become more modern and be augmented with contemporary information technology solutions which provide new informational and communication technologies and broadband wireless internet for smart work possibilities. Survey on the use of Latvian Public libraries shows that internet and library facilities for work related things has used $71.3 \%$ of all respondents $(n=646)$ in the year 2011 (SKDS, 2011).

Probably the future role of the library could be seen as a knowledge space for both formal work and informal encounter and for creating knowledge environment that encourages exchange of experience and information, as well as creating new ideas and knowledge. Therefore, in Latvia the future perspective of smart work and smart work centres would be to consider establishing alternatives to the traditional library space, such as libraries that are integrated with other types of institutions, as well as new flexible library services, including even job matching or start-up consultations. According to Del Aguila Obra et. al. (2002), "the most important aspect for the success of telecentres, is not merely the access to technology, but the capacity to understand the community where it is to be set up, and to adapt itself accordingly."

\section{Future steps and limitations}

The questionnaire has identified the needs of inhabitants in both city and rural municipalities in Latvia, including two sample municipalities - Balvi and Limbazi - which are facing socioeconomic challenges(lower economic activity and consequently depopulation, unemployment, ageing) with different severity due to their proximity to the economic centre of Latvia the capital city Riga. If other municipalities are planning to establish a smart work centre they should conduct similar, perhaps shorter and more focused, survey. Moreover, this survey refers to the potential not actual use of telework therefore additional surveys are needed if one wants to get a more precise picture of the use of telework in Latvia.

The research will be continued by surveying and interviewing employers to evaluate the current and potential supply of telework in rural areas. As a result national and local level policy guidelines will be proposed for the facilitation of telework and the creation of smart work centres. 


\subsection{Conclusions}

ICT and the rise of digital economy bring new solutions for workers in cities and rural areas. Defined as working outside the conventional workplace and communicating with it by way of telecommunications or computer-based technology smart work has many potential benefits for workers and employers. However the facilitation of smart work requires a shift in corporate culture and ways in organising our life in general.

From a regional and local point of view, telework is a welcome opportunity to digitally participate from distant locations, including rural towns, in the knowledge economy. Thus it may serve as an instrument for regional development by attracting people to rural areas or at least keeping people from moving to metropolitan areas.

This research shows that the majority of working age people in cities as well as in rural areas is willing to be involved in telework. People in less populated areas are also interested in socialising and networking activities. Still smart work remains to be largely urban phenomena. Therefore further research is required in order to offer sustainable solutions for telework in rural areas.

\section{Acknowledgment}

This work has been supported by the European Regional Development Fund within the INTERREG IVC project Micropol - Smart Work Centres in Non-Metropolitan Areas (No 1097R4). Our deepest gratitude belongs to prof. LienaAdamsone for assistance in developing the questionnaire and to prof. Karlis-Agris Gross for his advice and constructive criticism regarding this article.

\section{References}

[1] Bailey, D. E. \& Kurland, N. B. (2002). A review of telework research: findings, new directions, and lessons for the study of modern work. Journal of Organizational Behaviour 23(4), pp. 383-400. Doi: 10.1002/job.144.

[2] Baltina, I. \& Vitola, A. (2012). Telework - New Way of Working in $21^{\text {st }}$ Century. Proceedings of International Conference Trends in Economics and Management for the $21^{\text {st }}$ Century. Brno, University of Technology.

[3] Brette, O. \& Moriset, B. (2009). Bringing Down Territorial Inequalities in the Digital Economy: An Evolutionary Institutional Approach. Journal of Economic Issues 43(2), pp. 495-502.

[4] Bulderberga, Z., Krievina, A., Leimane, I., Lismanis, A., Miglavs, A., Skinkis, P. \& Vilka, I. (2011). Latvijas Lauku telpas attīstība un tās iespējamie nākotnes scenāriji. Riga: Latvian State Institute of Agrarian Economics.

[5] Creating jobs through NBN - enabled telework (2012). Canberra: Australian Government, Department of Broadband, Communications and the Digital Economy.

[6] Del Aguila Obra, A. R., Camara, S. B. \& Melendez, A. P. (2002). The economic and organizational aspects of telecentres: the Spanish case. Technovation 22(12), pp.785-798. Doi: 10.1016/S0166-4972(02)00032-9.

[7] Gareis, K. (2002). The Intensity of Telework in 2002 in the EU, Switzerlandand and the USA. Bonn: Gesellschaft fur Kommunikations - und Technologieforschung $\mathrm{mbH}$.

[8] Gratton, L. (2011). The Shift. The future of work is already here. New York: HarperCollins.

[9] Grimes, S. (2000). Rural areas in the information society: diminishing distance or increasing learning capacity? Journal of Rural Studies 16(1), pp. 13-21. Doi: 10.1016/S0743-0167(99)00027-3. 
[10] Kārklinga, I. (2011). Latvijas publiskās bibliotēkas un internets: tehnoloǵijas, pakalpojumi un ietekme uz sabiedrību. Riga: State agency Culture Information Systems.

[11] Krisjane, Z., Eglite, P., Bauls A., Lulle, A., Berzins, M., Brants, M., Cunska, Z., Gnedovska, I., Ivbulis, B., Kruzmetra, Z., Kule, L., Markausa, I. M., Niklass, M., Pavlina, I., Titova, N., Vanaga, S., Vilcins, A. \& Zarina, I. B. (2007). Darbaspēka ǵeogrāfiskā mobilitāte. Riga: University of Latvia.

[12] Krugman, P. (1998). What's New About the Economic Geography? Oxford Review of Economic Policy 14(2), 7-17. Doi: 10.1093/oxrep/14.2.7.

[13] Lister, K. (2012). The Who, What, Where, and Why Not of Telecommuting. Workshifting. Available: http://www.workshifting.com/2011/06/the-who-what-where-and-why-not-oftelecommuting.html [Accessed: June 26, 2012].

[14] Locane, V., Peipina, I., Brunenieks, J., Vilka, I., Skinkis, P., Ozolina, L., Kondratenko, J., Hermansons, Z., Ozols, G., Valeniece, D. \& Miglavs, A. (2011). Regionu attīstība Latvijā 2010. Riga: State Regional Development Agency.

[15] Moller, J. (2012). Big Changes in the Local Welfare System. Stockholm: NORDREGIO. Available: http://www.nordregio.se/en/Metameny/Nordregio-News/Quality-of-Life-in-anUrban-Rural-Perspective/Big-Changes-in-the-Local-Welfare-System/.

[16] Nilles, J. M. (1975). Telecommunications and organizational decentralization. IEEE Transactions On Communications. COM-23(10), 1142-1147.

[17] Nilles, J. M. (1994). Making Telecommuting Happen: A Guide for Telemanagers and Telecommuters. New York: Van Nostrand Reinhold.

[18] Nuur, C. \& Laestadius, S. (2009). Is the 'Creative Class' Necessarily Urban? Putting the Creativity Thesis in the Context of Non-urbanised Regions in Industrialised Nations. European Journal of Spatial Development.

[19] Olson, M. H. \& Primps, S. B. (1984). Working at home with computers: work and non-work issues. Journal of Social Issues 40(3), 97-112. Doi: 10.1111/j.1540-4560.1984.tb00194.x.

[20] Ozias, A., ed., (2011). Telework 2011. A WorldatWork Special Report. Washington: WorldatWork.

[21] Pyoria, P. (2003). Knowledge work in distributed environments: issues and illusions. New Technology, Work and Employment 18(3), 166-180. Doi: 10.1111/1468-005X.00119.

[22] Vermeylen, G. \& Hurley, J. (2007). Varieties of flexicurity: reflections on elements of flexibility and security. Dublin: European Foundation for the Improvement of Living and Working Conditions.

[23] Welz, C. \& Wolf, F. (2010). Telework in the European Union. Dublin: European Foundation for the Improvement of Living and Working Conditions.

[24] Zvidrina, S., Peipina, I., Locane, V., Pule, G., Vilka, I., Puzulis, A., Belkule, A., Kondratenko, J., Hermansons, Z. \& Bruninieks, J. (2012). Regionu attīstība Latvijā 2011. Riga: State Regional Development Agency.

\section{Web references}

Central Statistical Bureau of Republic of Latvia (2012). Database. Available: http://www.csb.gov.Iv/dati/statistikas-datubazes-28270.html [Accessed: September 1, 2012]

Connected urban development (2012). Connected and sustainable work: Smart work centre overview. Available:

http://www.connectedurbandevelopment.org/connected_and_sustainable_work/smart_work_ce nter [Accessed: July 21, 2012] 
Micropol - Smart Work Centres in Non-Metropolitan Areas (2012). SWC projects. Available: http://www.micropol-interreg.eu/

OECD: Organisation for Economic Co-operation and Development (2008). Tele-work growth 'too slow'. Available: http://www.euractiv.com/infosociety/tele-work-growth-slow-oecd/article172522 